\title{
Determinants of Capital Structure and Testing of Theories: A Study on the Listed Manufacturing Companies in Bangladesh
}

\author{
Md. Imran Hossain ${ }^{1} \&$ Md. Akram Hossain ${ }^{2}$ \\ ${ }^{1}$ Department of Finance, Faculty of Business Studies, University of Dhaka, Bangladesh \\ ${ }^{2}$ Department of Management and Information Systems (MIS), Faculty of Business Studies, University of Dhaka, \\ Bangladesh \\ Correspondence: Md. Imran Hossain, Lecturer, Department of Finance, Faculty of Business Studies, University \\ of Dhaka, Bangladesh. Tel: 880-16-7555-0775. E-mail: imran@du.ac.bd
}

Received: January 29, 2015

Accepted: February 16, 2015

Online Published: March 25, 2015

doi:10.5539/ijef.v7n4p176

URL: http://dx.doi.org/10.5539/ijef.v7n4p176

\begin{abstract}
The objectives of this study are to identify the significant determinants of capital structure of the listed manufacturing companies in Bangladesh and to test the relevant capital structure theories. This study used a panel dataset including 74 manufacturing companies listed under 8 industries in Dhaka Stock Exchange (DSE) for the period of 2002-2011. The Unit Root tests suggested that all series were stationary. Using Panel Corrected Standard Error Regression Model and Random Effects Tobit Regression Model, all selected variables were found significant. Managerial ownership positively and Growth rate, Profitability, Debt service coverage ratio, Non-debt tax shield, Financial costs, Free cash flow to firm, Agency costs and Dividend payment negatively affect the capital structure. Tangibility and Liquidity ratio have positive relationship with Long term debt and negative relationship with Short term debt and Total debt. It was also found that Pecking-order theory and Static Trade-off theory are the most dominant capital structure theories in Bangladesh. The policy implication is that the financial managers should consider these determinants as yardsticks before taking the leverage decisions in order to choose the most favorable capital structure for the company so that it maximizes the shareholders' value.
\end{abstract}

Keywords: Bangladesh, capital structure, debt ratio, determinants, leverage

\section{Introduction}

Now-a-days, optimal capital structure determination has become one of the most researched topics in both theoretical and empirical literature in the corporate finance arena. The term 'Capital Structure' refers to the amalgamation of various funding sources constituting the total assets of a company. Capital structure decisions facilitate a company to maximize its shareholders' values, allocate risks and control power among different groups of stakeholders. Proper choice of capital structure enables a company to accelerate its performance in a better way, ensure the sustainability of its operations and eventually accomplish its strategic goals. That's why the question that what factors significantly persuade the capital structure decisions of a company has got special value to the researchers as well as to the financial managers. After the pioneering publication of the Modigliani and Miller (1958) concerning the relevance of capital structure choices on firm value, several capital structure theories (i.e. Agency theory, Pecking-order theory, Static Trade-off theory, Free Cash Flow theory, Signaling theory etc.) have been emerged with a view to helping companies determine the optimal capital structure. But unfortunately, even after decades of research, none of these theories have been acknowledged as universal theory of capital structure, which leaves the topic open for further research.

In Bangladesh, one of the Least Developed Countries (LDCs) in South Asia, although there are very few researches focusing on the primary determinants of capital structure; there is still disagreement regarding the influencing factors of optimal capital structure decisions. Furthermore, all possible factors affecting capital structure decisions have not been considered in a study at a time and there is a necessity to test which capital structure theories are consistent in case of Bangladeshi companies.

The main purpose of this study is to determine the significant factors influencing the capital structure decisions of the listed manufacturing companies in Bangladesh. In addition, this study also aims at testing the relevant capital structure theories applicable in Bangladesh. Unlike the previous studies in Bangladesh, this study 
includes the largest panel data set (i.e. 74 listed manufacturing companies for 10 years period (2002-2011); that means 740 observations) and three different empirical regression models having maximum independent variables at a time and also Unit Root Tests in order to check the stationarity of the variables. The rest of the paper is structured as follows: Section two represents the theoretical discussion on capital structure and Section three contains the review of relevant literature. Empirical methodology, Empirical results and Testing of capital structure theories are analyzed in Section four, five and six respectively. Finally the conclusion and policy implications are discussed in Section seven.

\section{Theoretical Discussion on Capital Structure}

For the first time, Modigliani and Miller (1958) argued that in a tax free world, the market value of a firm remains constant irrespective of the capital structure choice, which denotes the irrelevance of capital structure. Again in 1963, incorporating corporate tax, they argued that the value of a levered firm will be greater than the value of an unlevered firm due to the interest tax shield on debt, which makes the capital structure relevant for a firm. According to these theories, there is no optimal capital structure. On the contrary, Scott (1977) stated in the Static Trade-off theory that an optimal capital structure can be attained at the trade-off point between interest tax shield and financial distress cost. This theory implies that debt financing is preferred till the optimal level and equity is preferred after the optimal level.

Another renowned theory, called Agency Theory, introduced by Jensen and Meckling (1976), suggests that an optimal capital structure requires the minimization of the agency cost by increasing the ownership of the managers in the firm or taking more debt to control managers' tendency for excessive perk consumptions. Free Cash Flow Theory, developed by Jensen (1986), states that managers with excess free cash flows tend to invest in matured or ill-advised projects that lessen shareholders' wealth and this problem can be solved by taking more debt or paying more dividends.

Ross (1977) stated in the Signaling Theory, based on asymmetric information, that managers use leverage decision to give signal to the market because investors treat debt financing as a signal of high future performance and high future cash flows of the firm. On the contrary, The Pecking Order Theory, introduced by Myers and Majluf (1984), states that there is no optimal capital structure and managers follow a hierarchy of preferences for the issuance of new capital based on the cost of capital. They prefer retained earnings as the main source of financing due to its zero cost and then debt financing, followed by equity financing, because cost of debt is less than that of equity.

\section{Literature Review}

Several empirical studies regarding capital structure decisions have been concisely reviewed here in terms of two segments i.e. International evidence and Evidence from Bangladesh.

\subsection{International Evidence}

In USA, Rajan and Zingales (1995) found that the significant determinants of capital structure of US companies are size, growth, profitability and tangible assets. Besides these factors, Graham and Harvey (2001) and Frank and Goyal (2007) claimed that US firms emphasize more on financial flexibility, credit rating, expected inflation and stock price increase rather than asymmetric information, tax shield, transaction costs, free cash flows and they also found the evidence of the Pecking-order theory and Trade-off theory.

In UK, Bevan and Danbolt (2000) found that large companies having high growth opportunities used less bank debt compared to smaller firms. Bancel and Mittoo (2004) surveyed managerial behavior and concluded that financial flexibility, credit rating and market timing are the most significant determinants of leverage decisions of European firms.

Recently Mishra (2011), analyzing the Indian manufacturing companies, claimed asset tangibility, profitability and tax to be significant factors whereas size, volatility and non-debt tax shield to be insignificant factor affecting the capital structure decisions. On the contrary, Rao and Jijo (1992) and Pathak (2005) found that size, risk, profitability, liquidity tangibility, tax and growth rate were significant determinants of capital structure.

In Pakistan, Mazhar and Nasr (2010), Rafiq et al. (2008) and Shah and Hijazi (2004), found that earnings volatility, profitability, non-debt tax shield asset tangibility, size and growth are the major factors affecting leverage decisions.

In Nepal, Baral (2004) showed a positive influence of operating leverage, dividend payout ratio, business risk, growth rate and size but negative influence of debt service capacity and profitability on leverage ratio.

Pandey (2001) in Malaysia, Huang and Song (2002) in China and Hassan (2011) in Nigeria found that leverage 
decisions are mainly influenced by ownership structure, profitability, size, growth, volatility, tangibility etc. On the contrary, Vasiliou and Daskalakis (2006) showed that financial distress, market timing and competitiveness are significant factors influencing leverage decisions in Greece.

\subsection{Evidence from Bangladesh}

For the first time in Bangladesh, Chowdhury (2004) investigated the cross-sectional differences in capital structure of Bangladeshi and Japanese firms based on agency cost model and found that agency cost of debt, profitability, growth rate, operating leverage and bankruptcy risk significantly influence the capital structure choice of both countries' firms. He also concluded that due to institutional differences, agency structures of these two countries' firms are different and especially Japanese firms can more effectively mitigate the agency conflicts compared to Bangladeshi firms due to better corporate governance mechanism in Japan.

On the other hand, Lima (2009), Sayeed (2011), Siddiqui (2012) and Hossain and Ali (2012) claimed that growth rate, tangibility, operating leverage, debt service capacity, managerial ownership age and size have significant influence on capital structure decisions. They also concluded that the agency cost theory and static trade-off theory are relevant for the companies in Bangladesh.

\section{Methodology}

\subsection{Data Sources and Sample Size}

To conduct this study, 10 years annual data (2002-2011) of 74 Bangladeshi manufacturing companies listed under 8 industries in Dhaka Stock Exchange (DSE) were collected from the DSE library. Table 1 shows the selected industries and number of companies from each selected industry used in this study.

Table 1. Frequency distribution of industry classification

\begin{tabular}{llllll}
\hline Sl. No. & Industry name & $\begin{array}{l}\text { No. of listed } \\
\text { companies }\end{array}$ & $\begin{array}{l}\text { No. of selected } \\
\text { companies }\end{array}$ & $\begin{array}{l}\text { No. of years } \\
\text { covered }\end{array}$ & $\begin{array}{l}\text { No. of } \\
\text { observations }\end{array}$ \\
\hline 1 & Cement & 7 & 4 & 10 & 40 \\
2 & Ceramic & 5 & 3 & 10 & 30 \\
3 & Engineering & 25 & 16 & 10 & 160 \\
4 & Food and Allied & 18 & 10 & 10 & 100 \\
5 & Jute & 3 & 2 & 10 & 20 \\
6 & Pharmaceuticals and Chemicals & 27 & 15 & 10 & 150 \\
7 & Tannery & 5 & 4 & 10 & 40 \\
8 & Textile & 34 & 20 & 10 & 200 \\
& Total & 124 & 74 & & 740 \\
\hline
\end{tabular}

\subsection{Measurements of the Variables}

\subsubsection{Dependent Variables}

Three different measurements of capital structure i.e. Short Term Debt Ratio (STDR), Long Term Debt Ratio (LTDR) and Total Debt Ratio (TDR) have been used as dependent variables, based on their book values, in this study. Their measurements are shown in Table 2.

Table 2. Measurements of the dependent variables

\begin{tabular}{llll}
\hline Sl. No. & Variable Indicators & Full name of the variables & Measurement (Proxy) \\
\hline 1 & STDR & Short Term Debt Ratio & Total Short Term Debt / Total Assets \\
2 & LTDR & Long Term Debt Ratio & Total Long Term Debt / Total Assets \\
3 & TDR & Total Debt Ratio & Total Debt / Total Assets \\
\hline
\end{tabular}

\subsubsection{Independent Variables}

This study used 12 independent variables including two dummy variables such as- dividend dummy and industry dummy. In case of industry dummy, the engineering industry has been considered as the base industry. Table 3 represents the measurements of the independent variables used in this study. 
Table 3. Measurements of the independent variables

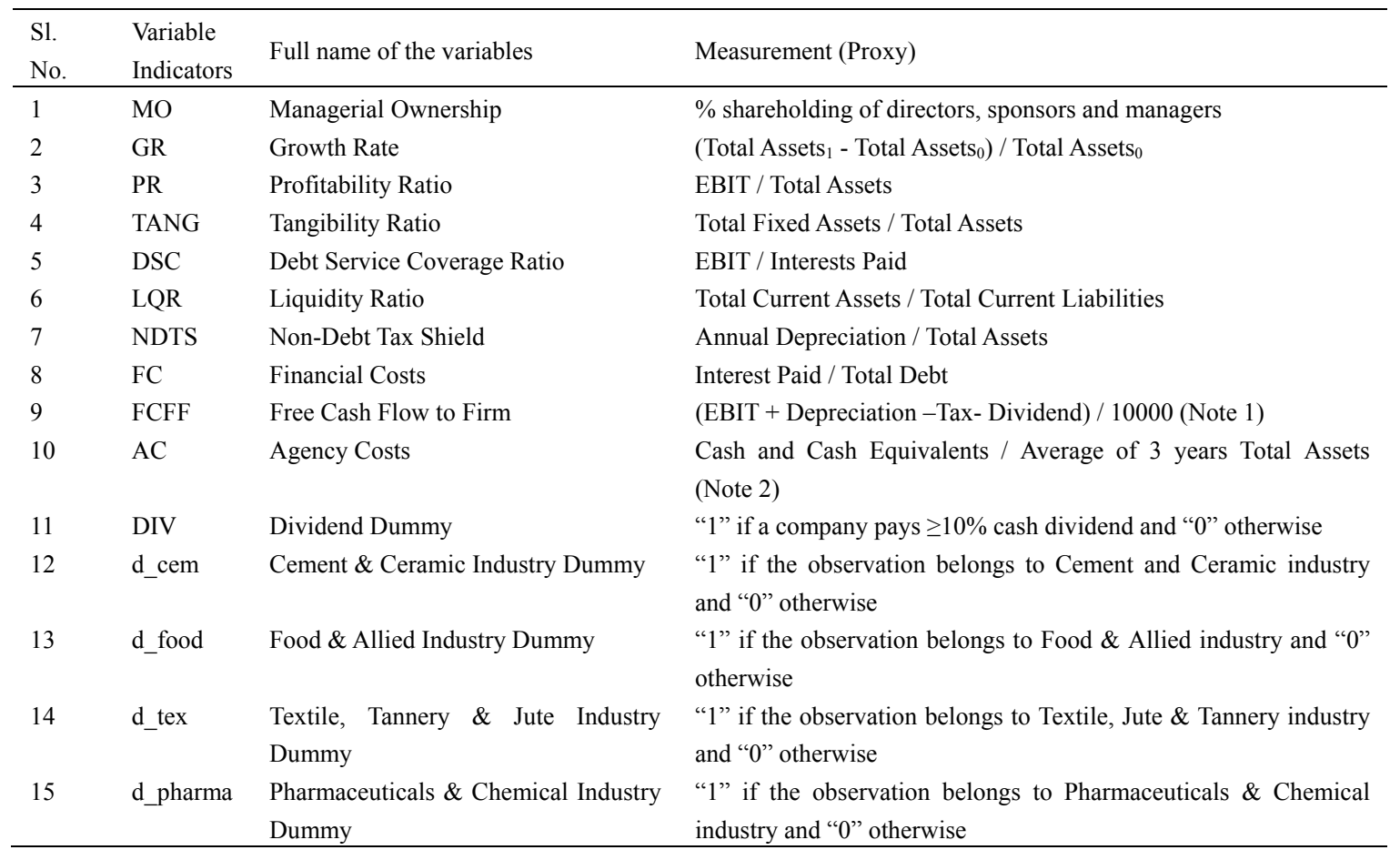

\subsubsection{Theoretical Expected Signs of Independent Variables}

Based on the five most renowned capital structure theories i.e. Agency theory, Static Trade-off theory, Pecking-order theory, Signaling theory and Free Cash Flow theory, we have derived the theoretical expected relationships of the independent variables with the leverage ratio which are shown in Table 4.

Table 4. Theoretical expected signs of independent variables

\begin{tabular}{llllll}
\hline \multirow{2}{*}{ Independent Variables } & \multicolumn{6}{l}{ Expected Signs } & & \\
\cline { 2 - 6 } & $\begin{array}{l}\text { Agency } \\
\text { theory }\end{array}$ & $\begin{array}{l}\text { Static Trade-off } \\
\text { theory }\end{array}$ & $\begin{array}{l}\text { Pecking-order } \\
\text { theory }\end{array}$ & $\begin{array}{l}\text { Signaling } \\
\text { theory }\end{array}$ & $\begin{array}{l}\text { Free Cash Flow } \\
\text { theory }\end{array}$ \\
\hline Managerial Ownership & - & - & + & & \\
Growth Rate & - & - & + & + & \\
Profitability Ratio & & + & - & \\
Tangibility Ratio & & + & - & \\
Debt Service Coverage Ratio & & + & - & \\
Liquidity Ratio & & + & - & \\
Non-Debt Tax Shield & & - & & & \\
Financial Costs & & - & - & \\
Free Cash Flow to Firm & & & & & \\
Agency Costs & - & & & & \\
Dividend Dummy & & & & & \\
\hline
\end{tabular}

Source: Authors' estimation.

\subsection{Specification of the Model}

Based on the three dependent variables used in this study, we have designed three multiple regression models to estimate the significant determinants of capital structure. They are as follows:

\section{Model I - STDR:}

$$
\begin{aligned}
& S T D R=\alpha+\beta_{1} M O_{i, t}+\beta_{2} G R_{i, t}+\beta_{3} P R_{i, t}+\beta_{4} T A N G_{i, t}+\beta_{5} D S C_{i, t}+\beta_{6} L Q R_{i, t}+\beta_{7} N D T S_{i, t}+\beta_{8} F C_{i, t}+\beta_{9} F C F F_{i, t} \\
& +\beta_{10} A C_{i, t}+\beta_{11} D I V_{i, t}+\beta_{12} d \_c e m_{i, t}+\beta_{13} d \text { food }_{i, t}+\beta_{14} d \_ \text {tex }{ }_{i, t}+\beta_{15} d \text { pharma }_{i, t}+\varepsilon_{i, t}
\end{aligned}
$$




\section{Model II - LTDR:}

$$
\begin{aligned}
& L T D R=\alpha+\beta_{1} M O_{i, t}+\beta_{2} G R_{i, t}+\beta_{3} P R_{i, t}+\beta_{4} T A N G_{i, t}+\beta_{5} D S C_{i, t}+\beta_{6} L Q R_{i, t}+\beta_{7} N D T S_{i, t}+\beta_{8} F C_{i, t}+\beta_{9} F C F F_{i, t} \\
& +\beta_{10} A C_{i, t}+\beta_{11} D I V_{i, t}+\beta_{12} d \_c e m_{i, t}+\beta_{13} d \_ \text {food }_{i, t}+\beta_{14} d \_t e x_{i, t}+\beta_{15} d \_ \text {pharma }_{i, t}+\varepsilon_{i, t}
\end{aligned}
$$

Model III - TDR:

$$
\begin{aligned}
T D R= & \alpha+\beta_{1} M O_{i, t}+\beta_{2} G R_{i, t}+\beta_{3} P R_{i, t}+\beta_{4} T A N G_{i, t}+\beta_{5} D S C_{i, t}+\beta_{6} L Q R_{i, t}+\beta_{7} N D T S_{i, t}+\beta_{8} F C_{i, t}+\beta_{9} F C F F_{i, t} \\
& +\beta_{10} A C_{i, t}+\beta_{11} D I V_{i, t}+\beta_{12} d_{-} \text {cem } \\
i, t & +\beta_{13} d_{\text {food }} \text { foot }_{i, t}+\beta_{14} d_{\text {t tex }}+\beta_{1, t} d \_ \text {pharma } \\
i, t & +\varepsilon_{i, t}
\end{aligned}
$$

Where, $i$ refers to the individual companies and $t$ refers to the time period.

\subsection{Research Methods}

\subsubsection{Unit Root Tests}

A data series is said to be non-stationary if it does not have a constant mean, variance and auto-covariance at various lags over time (Gujarati, 2007). Applying econometric models on non-stationary series produces spurious and misleading results. To check the unit root of the series, we have applied two different types of unit root tests, i.e. Levin-Lin-Chu (LLC) test and Fisher-type Augmented Dickey Fuller (ADF) test, in this study to avoid the criticisms of individual test. We have done these two tests in terms of two assumptions i.e. random walk with drift and random walk with drift around a stochastic trend.

\subsubsection{Levin-Lin-Chu (LLC) Test}

Levin, Lin and Chu (2002) proposed a unit root test named Levin-Lin-Chu (LLC) Test which is used in case of strongly balanced panel dataset (Note 3). This test is estimated assuming that there is a common unit root process (homogenous) so that AR parameter is identical across cross-sections. The null hypothesis of this test is that each panel contains unit root against the alternative that each panel is stationary. The model is given below:

$$
\Delta Y_{i t}=\rho_{i} Y_{i, t-1}+Z_{i t}^{\prime} \gamma_{i}+\sum_{j=1}^{p} \boldsymbol{\theta}_{i j} \Delta Y_{i, t-j}+u_{i t}
$$

Where $i=1,2, \ldots, \mathrm{N}$ cross section series; $t=1,2, \ldots, \mathrm{T}$ time periods; $Y_{i t}$ is the exogenous variable being tested; $\rho_{i}$ is the autoregressive coefficients; $Z_{i t}^{\prime}=(1, t)$ so that the term $Z_{i t}^{\prime} \gamma_{i}$ represents panel-specific means and linear time trends; and $\varepsilon_{i t}$ is a stationary error term which is assumed to be mutually independent idiosyncratic disturbance. Here, the number of lags, $p$, is selected automatically by the software that minimizes Schwarz Information Criteria (SIC).

\subsubsection{Fisher - Type ADF Test}

Choi (2001) proposed a Fisher-type test which performs a unit root test on each panel's series separately and then combines the $p$-values from each cross section to obtain an overall test statistic by using Monte Carlo simulations. Unlike LLC test, this test does not require strongly balanced panel dataset. It assumes individual unit root process (heterogeneous) so that AR parameter is different across cross-sections. We have performed Fisher-type Augmented Dickey Fuller (ADF) test in this study. This test has the following model:

$$
P=-2 \sum_{i=1}^{N} \ln \left(p_{i}\right) \rightarrow \chi^{2}(2 N)
$$

Here, $p_{i}$ represents each cross-section panel and $\ln$ is the Natural Logarithm. This test is asymptotically chi-square distributed with $2 \mathrm{~N}$ degrees of freedom.

\subsubsection{Multicollinearity Test}

When the exogenous variables are significantly correlated with each other, it is called Multicollinearity problem. To test Multicollinearity in the dataset, We have used Pearson (1896) Product-Moment Correlation Coefficient.

The estimate of the product-moment correlation coefficient, $\rho$, is:

$$
\hat{\rho}=\frac{\sum_{i=1}^{n} W_{i}\left(x_{i}-\bar{x}\right)\left(y_{i}-\bar{y}\right)}{\sqrt{\sum_{i=1}^{n} W_{i}\left(x_{i}-\bar{x}\right)^{2}} \sqrt{\sum_{i=1}^{n} W_{i}\left(y_{i}-\bar{y}\right)^{2}}}
$$


Here, $w_{i}$ is the weights, if specified or $w_{i}=1$ if weights are not specified. And $\bar{x}=\left(\sum w_{i} x_{i}\right) /\left(\sum w_{i}\right)$ is the mean of $\mathrm{x}$ and $\bar{y}=\left(\sum w_{i} y_{i}\right) /\left(\sum w_{i}\right)$ is the mean of $\mathrm{y}$.

\subsubsection{Heteroscedasticity Test}

When the errors don't have constant variance, then the dataset faces the problem of heteroscedasticity and if the regression is run on the dataset having heteroscedasticity, the $t$ - test and $\mathrm{F}$ - test give inaccurate results (Gujarati, 2007). To test heteroscedasticity, I have used White test introduced by White (1980). In this test, the squared residuals obtained from the original regression are regressed on the independent variables, their squared values and their cross-products. The null hypothesis is that there is no heteroscedasticity. In this test, the sample size $(n)$ times the $R^{2}$ value from the regression asymptotically follows the $\chi^{2}$ distribution and the $d f$ is the number of independent variables (excluding constant). That means, $n * R^{2} \sim \chi_{d f}^{2}$. If the obtained $\chi^{2}$ value is greater than the critical $\chi^{2}$ value, the null hypothesis is rejected and vice-versa. The auxiliary regression model for White test in case of Model I is as follows:

$$
\begin{gathered}
(\text { Residual_STDR })^{2}=\alpha+\beta_{1} M O+\beta_{2} G R+\beta_{3} P R+\beta_{4} T A N G+\beta_{5} D S C+\beta_{6} L Q R+\beta_{7} N D T S+\beta_{8} F C+\beta_{9} F C F F+ \\
\beta_{10} A C+\beta_{11} M O^{2}+\beta_{12} G R^{2}+\beta_{13} P R^{2}+\beta_{14} T A N G^{2}+\beta_{15} D S C^{2}+\beta_{16} L Q R^{2}+\beta_{17} N D T S^{2}+\beta_{18} F C^{2}+\beta_{19} F C F F^{2}+ \\
\beta_{20} A C^{2}+\beta_{21} M O^{*} G R+\beta_{22} P R^{*} T A N G+\beta_{23} D S C^{*} L Q R+\beta_{24} N D T S^{*} F C+\beta_{25} F C F F^{*} A C+\mathcal{E}_{1}
\end{gathered}
$$

In case of Model II and III, only the dependent variable is replaced by (Residual_LTDR) ${ }^{2}$ and $\left(\right.$ Residual_TDR) ${ }^{2}$ respectively.

\subsubsection{Autocorrelation Test}

Durbin-Watson $d$ statistic, proposed by Durbin and Watson (1950), was used to test first order serial correlation in the disturbance assuming all the regressors are strictly exogenous. The Durbin-Watson d statistic can also be described in terms of $\rho$ (rho) i.e. $d \approx 2(1-\rho)$ (Gujarati, 2007). Here, $\rho$ (rho) is the coefficient of first order autocorrelation. In this study, Random Effects GLS regression model has been applied to determine that value of $\rho$ (rho) based on Durbin-Watson and then value of $d$ statistic has been calculated.

\subsubsection{Panel Corrected Standard Error (PCSE) Regression Model}

We have used Panel Corrected Standard Error (PCSE) model to determine the significant impacts of the determinants of capital structure. PCSE is an alternative to the Feasible Generalized Least Squares (FGLS) for fitting the panel data models when the errors are not independent and identically distributed; rather the errors are either heteroscedastic across panels or heteroscedastic and contemporaneously correlated across panels, with or without autocorrelation (Kmenta, 1997). The reason for using this model is that it automatically corrects the heteroscedasticity and autocorrelation problem and provides the best estimates for the variables.

The model can be written as:

$$
y_{i t}=\beta_{X_{i t}}+\varepsilon_{i t}
$$

Where $i=1, \ldots ., n$ is the number of panels; $t=1, \ldots \ldots, T_{i}$ is the number of periods in panel $i$ and $\varepsilon_{i t}$ is the errors autocorrelated along $t$ or contemporaneously correlated across $i$.

This model can also be expressed panel by panel as:

$$
\left[\begin{array}{l}
y_{1} \\
y_{2} \\
\cdot \\
\cdot \\
y_{n}
\end{array}\right]=\left[\begin{array}{l}
x_{1} \\
x_{2} \\
\cdot \\
\cdot \\
x_{n}
\end{array}\right] \beta+\left[\begin{array}{l}
\varepsilon_{1} \\
\varepsilon_{2} \\
\cdot \\
\cdot \\
\varepsilon_{n}
\end{array}\right]
$$

If autocorrelation is specified, the parameters $\beta$ are estimated by Prais-Winsten (1954).

\subsubsection{Random Effects Tobit Regression Model}

Since some companies didn't have long term debt (that means some of the values of dependent variable LTDR in Model II was 0), we have also run Random Effects Tobit Regression Model, developed by Honore (1992), in order to verify the results obtained from the PCSE model. This model deals with the censored outcomes i.e. when the dependent variable has a value of 0 . Consider the following regression model with panel level random 
effects:

$$
y_{i t}=x_{i t} \beta+v_{i}+\varepsilon_{i t}
$$

Where $i=1, \ldots . ., n$ panels; $t=1, \ldots ., T_{i}$ periods in panel $i ; v_{i}$ are the random effects such that $N=\left(0, \sigma_{v}^{2}\right)$ and $\varepsilon_{i t}$ is independent of $v_{i}$ such that $N=\left(0, \sigma_{\varepsilon}^{2}\right)$. The observed data, $\hat{y}_{i t}$, represent the censored versions of $y_{i t}$. If they are left-censored (i.e. $y_{i t} \leq \hat{y}_{i t}$ ), $\hat{y}_{i t}$ is determined by Lower limit and if they are right-censored (i.e. $y_{i t} \geq \hat{y}_{i t}$ ), $\hat{y}_{i t}$ is determined by Upper limit and if they are uncensored (i.e. $y_{i t}=\hat{y}_{i t}$ ), $\hat{y}_{i t}$ is determined by the dependent variable.

\section{Empirical Results Analysis}

\subsection{Descriptive Statistics}

Table 5 represents the descriptive statistics of the variables used in this study in terms of their mean, standard deviation, minimum and maximum values. It is evident that the manufacturing companies of Bangladesh finance on an average $60.85 \%$ of total assets with debts comprising of $44.96 \%$ with short term debts and $15.89 \%$ with long term debts respectively. It indicates that the companies are more interested in short term financing than long term financing.

Table 5. Descriptive statistics of the variables

\begin{tabular}{llllll}
\hline & Mean & Standard Deviation & Maximum & Minimum & Observations \\
\hline STDR & 0.4496 & 0.2110 & 1.8099 & 0.0104 & 740 \\
LTDR & 0.1589 & 0.1801 & 0.9433 & 0 & 740 \\
TDR & 0.6085 & 0.2420 & 1.8179 & 0.0427 & 740 \\
MO & 0.4677 & 0.1669 & 0.9167 & 0 & 740 \\
GR & 0.1278 & 0.3513 & 4.8174 & -0.3429 & 740 \\
PR & 0.0884 & 0.0833 & 0.5671 & -0.1248 & 740 \\
TANG & 0.4319 & 0.214 & 0.9400 & -0.3977 & 740 \\
DSC & 73.28 & 1435 & 38794 & -2163 & 740 \\
LQR & 1.82 & 3.8303 & 75.010 & 0.1387 & 740 \\
NDTS & 0.2507 & 1.8982 & 20.11 & -0.68 & 740 \\
FC & 0.0590 & 0.0448 & 0.3773 & 0 & 740 \\
FCFF & $394.69 \mathrm{mln}$ & $698.95 \mathrm{mln}$ & $5640.86 \mathrm{mln}$ & $-292.38 \mathrm{mln}$ & 740 \\
AC & 0.0503 & 0.0977 & 0.8367 & 0 & 740 \\
\hline
\end{tabular}

Note. All the variables are in ratio form except DSC \& LQR are in times and FCFF is in TK (in million).

The table also shows that $46.77 \%$ of the shares are held by the directors, sponsors and managers which indicate great influencing power of these parties on the decision making of the companies. Also the companies grow on an average at $12.78 \%$ and make profit at $8.84 \%$ per year which is satisfactory indeed. The companies have about 43.19\% net fixed assets and TK. 73.28 EBIT for paying TK. 1 interest on debt which indicates their strong ability to service the debts. Also they have TK. 1.82 of current assets against current liability of TK. 1 which indicates their strong liquidity position.

\subsection{Results of Unit Root Tests}

The results of two unit root tests i.e. LLC test and Fisher-type ADF test are given in Table 6. Here, it is evident that all the variables are stationary under these two tests. One little exception is that FCFF is non-stationary only in case of individual intercept in both tests. Since the assumption with individual intercept \& trend is a better estimator of unit root compared to only individual intercept, FCFF has been treated as stationary series. 
Table 6. Results of unit root tests

\begin{tabular}{|c|c|c|c|c|c|c|}
\hline \multirow{3}{*}{ Variables } & \multicolumn{6}{|c|}{$\begin{array}{l}\text { Levin, Lin \& Chu Test } \\
\text { Null: Unit root (assumes common unit root process) }\end{array}$} \\
\hline & \multicolumn{3}{|c|}{ (With Individual Intercept) } & \multicolumn{3}{|c|}{ (With Individual Intercept \& Trend) } \\
\hline & t-statistic & Probability & Process & t-statistic & Probability & Process \\
\hline STDR & $-8.45 * * *$ & 0.0000 & $\mathrm{~S}$ & $-14.21 * * *$ & 0.0000 & $\mathrm{~S}$ \\
\hline LTDR & $-125.78 * * *$ & 0.0000 & S & $-146.18^{* * *}$ & 0.0000 & $\mathrm{~S}$ \\
\hline TDR & $-8.88 * * *$ & 0.0000 & S & $-13.04 * * *$ & 0.0000 & S \\
\hline MO & $-71.16^{* * *}$ & 0.0000 & S & $-81.86^{* * *}$ & 0.0000 & $\mathrm{~S}$ \\
\hline GR & $-40.76 * * *$ & 0.0000 & $\mathrm{~S}$ & $-32.79 * * *$ & 0.0000 & $\mathrm{~S}$ \\
\hline PR & $-9.56 * * *$ & 0.0000 & $\mathrm{~S}$ & $-12.26 * * *$ & 0.0000 & $\mathrm{~S}$ \\
\hline TANG & $-6.60 * * *$ & 0.0000 & S & $-56.67 * * *$ & 0.0000 & S \\
\hline DSC & $-690.62 * * *$ & 0.0000 & $\mathrm{~S}$ & $-422.98 * * *$ & 0.0000 & $\mathrm{~S}$ \\
\hline LQR & $-3.88 * * *$ & 0.0001 & $\mathrm{~S}$ & $-15.03 * * *$ & 0.0000 & $\mathrm{~S}$ \\
\hline NDTS & $-10.68 * * *$ & 0.0000 & $\mathrm{~S}$ & $-75.13 * * *$ & 0.0000 & $\mathrm{~S}$ \\
\hline $\mathrm{FC}$ & $-27320 * * *$ & 0.0000 & S & $-28078^{* * *}$ & 0.0000 & $\mathrm{~S}$ \\
\hline FCFF & 5.20 & 1.0000 & NS & $-4.90 * * *$ & 0.0000 & $\mathrm{~S}$ \\
\hline $\mathrm{AC}$ & $-22.49 * * *$ & 0.0000 & $\mathrm{~S}$ & $-25.85^{* * *}$ & 0.0000 & $\mathrm{~S}$ \\
\hline \multicolumn{7}{|c|}{$\begin{array}{l}\text { Fisher-type ADF Test } \\
\text { Null: Unit root (assume }\end{array}$} \\
\hline \multirow{2}{*}{ Variables } & \multicolumn{3}{|c|}{ (With 0Individual Intercept) } & \multicolumn{3}{|c|}{ (With Individual Intercept \& Trend) } \\
\hline & Chi-square statistic & Probability & Process & Chi-square statistic & Probability & Process \\
\hline STDR & $198.60 * * *$ & 0.0035 & S & $202.21 * * *$ & 0.0021 & $\mathrm{~S}$ \\
\hline LTDR & $228.11 * * *$ & 0.0000 & S & $214.52 * * *$ & 0.0001 & $\mathrm{~S}$ \\
\hline TDR & $201.36^{* * *}$ & 0.0023 & $\mathrm{~S}$ & $188.65^{* *}$ & 0.0134 & S \\
\hline MO & 115.67 & 0.1074 & NS & $123.23 *$ & 0.0748 & S \\
\hline GR & $375.40^{* * *}$ & 0.0000 & S & $291.06^{* * *}$ & 0.0000 & S \\
\hline PR & $247.79 * * *$ & 0.0000 & S & $187.46^{* *}$ & 0.0156 & S \\
\hline TANG & $195.74 * * *$ & 0.0052 & S & $215.78^{* * *}$ & 0.0002 & S \\
\hline DSC & $260.76^{* * *}$ & 0.0000 & S & $287.92^{* * *}$ & 0.0000 & S \\
\hline LQR & $192.82 * * *$ & 0.0078 & S & $216.44 * * *$ & 0.0002 & S \\
\hline NDTS & $254.76^{* * *}$ & 0.0000 & S & $238.11^{* * *}$ & 0.0000 & S \\
\hline $\mathrm{FC}$ & $257.99 * * *$ & 0.0000 & S & $218.58 * * *$ & 0.0001 & $\mathrm{~S}$ \\
\hline FCFF & 66.30 & 1.0000 & NS & 167.84 & 0.0264 & S \\
\hline $\mathrm{AC}$ & $308.64 * * *$ & 0.0000 & $\mathrm{~S}$ & $295.66^{* * *}$ & 0.0000 & $\mathrm{~S}$ \\
\hline
\end{tabular}

Note. Here "S" means Stationary and "NS" means Non-stationary. Also *,**,*** represent $10 \%, 5 \%$ and $1 \%$ level of significance respectively. The lag length is automatically selected based on Schwartz Information Criterion (SIC).

\subsection{Results of Multicollinearity Test}

Table 7 represents the results of Multicollinearity Test. If the correlation coefficient between two independent variables is about 0.80 or larger, there is Multicollinearity problem (Lewis-Beck, 1993). It is evident from the table that none of the pair-wise correlation coefficient is 0.80 or larger. So it can be concluded that there is no multicollinearity problem in the data set.

Table 7. Pearson's product-moment correlation coefficient results

\begin{tabular}{|c|c|c|c|c|c|c|c|c|c|c|}
\hline & $\mathrm{MO}$ & GR & PR & TANG & DSC & LQR & NDTS & $\mathrm{FC}$ & FCFF & $\mathrm{AC}$ \\
\hline $\mathrm{MO}$ & 1.00 & & & & & & & & & \\
\hline GR & -0.052 & 1.00 & & & & & & & & \\
\hline $\mathrm{PR}$ & 0.032 & 0.047 & 1.00 & & & & & & & \\
\hline TANG & -0.098 & 0.024 & -0.088 & 1.00 & & & & & & \\
\hline DSC & -0.076 & 0.002 & 0.037 & 0.017 & 1.00 & & & & & \\
\hline LQR & 0.104 & -0.002 & 0.008 & -0.065 & 0.063 & 1.00 & & & & \\
\hline NDTS & -0.090 & -0.035 & 0.046 & -0.161 & -0.007 & 0.006 & 1.00 & & & \\
\hline
\end{tabular}




\begin{tabular}{lllllllllll}
\hline FC & -0.070 & -0.113 & -0.033 & 0.056 & -0.065 & -0.008 & 0.038 & 1.00 & & \\
FCFF & -0.015 & 0.050 & 0.291 & 0.095 & -0.020 & -0.057 & 0.004 & -0.030 & 1.00 & \\
AC & 0.166 & 0.140 & 0.296 & -0.308 & 0.030 & 0.013 & -0.008 & -0.213 & -0.020 & 1.00 \\
\hline
\end{tabular}

\subsection{Results of Heteroscedasticity Test}

The results of White Test are presented in Table 8. It is evident from the table that all three models are facing the problem of heteroscedasticity.

Table 8. Results of White test

\begin{tabular}{|c|c|c|c|c|c|c|}
\hline Model \# & Overall $R^{2}$ & $\begin{array}{l}\text { No. of observations } \\
(n)\end{array}$ & $\begin{array}{l}\text { Obtained } \\
\chi^{2} \sim n * R^{2}\end{array}$ & $\begin{array}{l}\text { Critical } \chi^{2} @ 25 d f \& \\
5 \% \text { Sig. level }\end{array}$ & Decision & Heterosce-dasticity \\
\hline I (STDR) & 0.0678 & 740 & 50.17 & 37.65 & $\mathrm{H}_{\mathrm{o}}$ rejected & Yes \\
\hline II (LTDR) & 0.1178 & 740 & 87.17 & 37.65 & $\mathrm{H}_{\mathrm{o}}$ rejected & Yes \\
\hline III (TDR) & 0.0993 & 740 & 73.48 & 37.65 & $\mathrm{H}_{\mathrm{o}}$ rejected & Yes \\
\hline
\end{tabular}

\subsection{Results of Autocorrelation Test}

Durbin-Watson $d$ Statistic results are shown in Table 9. If the d statistic is less than the critical lower bound, there is positive autocorrelation and if the $d$ statistic is more than the critical upper bound, there is negative autocorrelation (Gujarati, 2007). Here, in all three models, the d statistic is lower than the critical lower bound. Hence, there is positive serial autocorrelation in the dataset.

Table 9. Results of Durbin-Watson $d$ statistic

\begin{tabular}{ccccc}
\hline Model \# & $\rho$ (rho) value & $\begin{array}{c}\text { Durbin-Watson } d \\
\text { Statistic } d \approx 2(1-\rho)\end{array}$ & $\begin{array}{c}\text { Critical Lower bound (@) } \\
5 \% \text { sig., K=15 \& T=740) }\end{array}$ & $\begin{array}{c}\text { Critical Upper bound (@ } \\
5 \% \text { sig., K=15 \& T=740) }\end{array}$ \\
\hline I (STDR) & 0.5001 & 0.75 & 1.84 & 1.92 \\
II (LTDR) & 0.7027 & 0.65 & 1.84 & 1.92 \\
III (TDR) & 0.7236 & 0.64 & 1.84 & 1.92 \\
\hline
\end{tabular}

\subsection{Results of Panel Corrected Standard Error (PCSE) Model}

The PCSE regression results of Model- I, II \& III are given in Table 10. In all models, we have assumed that the variables are positively correlated at lag 1 .

Table 10. PCSE regression results of model- I, II \& III

\begin{tabular}{|c|c|c|c|c|c|c|}
\hline \multicolumn{7}{|c|}{ Prais-Winsten regression, correlated panels corrected standard errors (PCSEs) } \\
\hline \multicolumn{7}{|c|}{ Group variable: company Number of obs. $=740$} \\
\hline \multicolumn{7}{|c|}{ Time variable: year Number of groups $=74$} \\
\hline \multicolumn{7}{|c|}{ Panels: correlated (balanced) Obs. per group: $\min .=10$} \\
\hline \multicolumn{7}{|c|}{ Autocorrelation: common AR (1) avg. $=10$} \\
\hline \multicolumn{7}{|l|}{ Max. $=10$} \\
\hline \multicolumn{7}{|c|}{ Estimated covariances $=2775$} \\
\hline \multicolumn{7}{|c|}{ Estimated autocorrelations $=1$} \\
\hline \multicolumn{7}{|c|}{ Estimated coefficients $=16$} \\
\hline \multirow{2}{*}{ Variables } & \multicolumn{2}{|c|}{ Model- I (STDR) } & \multicolumn{2}{|c|}{ Model- II (LTDR) } & \multicolumn{2}{|c|}{ Model- III (TDR) } \\
\hline & Coefficients & z statistic & Coefficients & z statistic & Coefficients & z statistic \\
\hline MO & -0.0182 & -0.27 & 0.1257 & $2.94 * * *$ & 0.1457 & $1.90 *$ \\
\hline GR & -0.0112 & -1.40 & -0.0268 & $-4.44 * * *$ & -0.0373 & $-3.56 * * *$ \\
\hline PR & -0.1365 & $-1.68^{*}$ & -0.0026 & -0.04 & -0.1285 & -1.38 \\
\hline TANG & -0.4540 & $-10.44 * * *$ & 0.1226 & $3.57 * * *$ & -0.3303 & $-7.94 * * *$ \\
\hline DSC & -0.000003 & -1.49 & -0.000002 & -1.58 & -0.000004 & $-1.72 *$ \\
\hline LQR & -0.0081 & $-3.95 * * *$ & 0.0043 & $2.01 * *$ & -0.0030 & $-2.43 * *$ \\
\hline NDTS & -0.0146 & $-2.80 * * *$ & 0.0003 & 0.11 & -0.0161 & $-2.82 * * *$ \\
\hline
\end{tabular}




\begin{tabular}{|c|c|c|c|c|c|c|}
\hline $\mathrm{FC}$ & -0.2641 & $-1.99 * *$ & -0.7024 & $-7.20 * * *$ & -0.9820 & $-8.34 * * *$ \\
\hline FCFF & -0.0000002 & $-2.59 * * *$ & -0.0000001 & -1.48 & -0.0000003 & $-3.22 * * *$ \\
\hline $\mathrm{AC}$ & -0.2576 & $-4.66 * * *$ & -0.0541 & -1.29 & -0.3100 & $-5.47 * * *$ \\
\hline DIV & -0.0263 & $-2.33 * *$ & -0.0018 & -0.28 & -0.0266 & $-2.48 * *$ \\
\hline d_cem & 0.0832 & $2.89 * * *$ & -0.0630 & $-2.31 * *$ & 0.0164 & 0.41 \\
\hline d_food & -0.0151 & -0.47 & 0.0189 & 0.68 & -0.0002 & -0.00 \\
\hline d_tex & 0.1154 & $3.68 * * *$ & 0.0262 & 1.08 & 0.1403 & $5.55 * * *$ \\
\hline d_pharma & 0.1009 & $3.25 * * *$ & -0.0615 & $-1.98 * *$ & 0.0390 & 1.10 \\
\hline _cons & 0.6729 & $13.43 * * *$ & 0.0948 & $3.23 * * *$ & 0.7455 & $13.87 * * *$ \\
\hline $\mathrm{R}^{2}$ & \multicolumn{2}{|c|}{0.3510} & \multicolumn{2}{|c|}{0.1977} & \multicolumn{2}{|c|}{0.4439} \\
\hline Prob. $>$ chi $^{2}$ & \multicolumn{2}{|c|}{0.000} & \multicolumn{2}{|c|}{0.000} & \multicolumn{2}{|c|}{0.000} \\
\hline
\end{tabular}

Note. Here, $*, * *$ and $* * *$ represent $10 \%, 5 \%$ and $1 \%$ significance level respectively.

We know that $\mathrm{R}^{2}$ (Coefficient of determination) is the measurement of goodness of fit. It shows how well the sample regression line fits the data. It is evident from the table that the combined variation in the independent variables can explain about 35.10\%, 19.77\% and 44.39\% variation in the dependent variable of Model- I, ModelII and Model- III respectively. These $\mathrm{R}^{2}$ values are greater than those of other studies i.e. Sayeed (2011), Siddiqui (2012) and Hossain and Ali (2012). Also Prob. $>$ chi $^{2}$ value (0.000) shows that the overall model is significant at $1 \%$ level in each of the three cases. All the variables' coefficients, significance and implications are discussed below:

\subsubsection{Managerial Ownership}

The results indicate that managerial ownership is positively related to LTDR and TDR at $1 \%$ and $10 \%$ significance level respectively. This result supports the prediction of Pecking-order theory. The reason for positive relationship is that sponsors, directors and managers holding the largest percentage of shareholding desire to concentrate ownership and control within themselves and so they don't go for equity financing, rather they take debt due to its lower cost and tax benefits. This positive result is consistent with Huang and Song (2002) and contradictory to Hossain and Ali (2012).

\subsubsection{Growth Rate}

Growth rate conforms to prediction of the Agency theory and Static trade-off theory since it has negative relationship with LTDR and TDR at 1\% significance level. This negative relationship can be attributed to the tendency of the companies, having high growth opportunities, to use limited debt because the value of those investment opportunities will be close to zero in case of bankruptcy. This negative result is consistent with Chowdhury (2004) and Rajan and Zingales (1995) and contradictory to Lima (2009) and Hossain and Ali (2012).

\subsubsection{Profitability Ratio}

A negative relationship between profitability ratio and leverage ratios is observed although it is significant in case of only STDR at $10 \%$ level. It is consistent with the Pecking-order theory implying that the more profitable companies prefer using internal financing to using debt in their capital structure. This negative result is consistent with Chowdhury (2004) and Hossain and Ali (2012) and contradictory to Sayeed (2011) and Siddiqui (2012).

\subsubsection{Tangibility}

The results show that tangibility is a robust significant factor influencing the leverage ratios as it is significant at $1 \%$ level in all models. It negatively affects STDR and TDR which conforms to the Pecking-order theory implying that the companies with lower level of tangible assets face information asymmetry problems that reduce the price of equity and hence, they go for debt financing. On the contrary, tangibility has a positive relationship with LTDR which is consistent with the Static Trade-off theory. The reason is that companies can use fixed assets as collateral for taking long term debt and the creditors feel relaxed to give long term loan to those companies having less possibility of bankruptcy due to their large amount of net fixed assets. The positive result is consistent with Rajan and Zingales (1995) and Lima (2009) whereas the negative result is consistent with Hossain and Ali (2012).

\subsubsection{Debt Service Coverage Ratio}

Debt Service Coverage Ratio has a negative relationship with all leverage ratios even though it is significant only in case of TDR at $10 \%$ level. The result is consistent with the prediction of Pecking-order theory because a 
company with high operating income can retain more earnings and use them in funding the future investments instead of using debts. This negative result is consistent with Siddiqui (2012) and contradictory to Lima (2009).

\subsubsection{Liquidity Ratio}

Liquidity Ratio has been found as a considerable determinant of capital structure as it is significant in case of all leverage ratios. The negative relationship with STDR and TDR conforms to the prediction of Pecking-order theory such that the companies with high liquidity are able to generate high cash inflows and use them for financing further investment opportunities. The negative result is consistent with Hossain and Ali (2012). On the contrary, it has a positive relationship with LTDR which is consistent with the prediction of Static Trade-off theory in such a way that the companies with high liquidity have more interest payment ability as well as less bankruptcy possibility and hence, the creditors feel comfortable to give long term loans to those companies.

\subsubsection{Non-Debt Tax Shield}

Non-debt Tax Shield has a significant negative relationship with STDR and TDR at 1\% level. This negative result conforms to the prediction of Static Trade-off theory implying that the companies having high depreciation and other non-cash expenditures prefer to use less debt in their capital structure. It is consistent with Sayeed (2011) and contradictory to Hossain and Ali (2012).

\subsubsection{Financial Costs}

The results suggest that Financial Cost has a very strong negative influence on the capital structure decisions of the manufacturing companies in Bangladesh. The prediction of Static Trade-off theory becomes true in this case because when the interest payments become high, the companies prefer to reduce the portion of debt in their capital structure in order to reduce the bankruptcy risks.

\subsubsection{Free Cash Flow to Firm}

Free Cash Flow to Firm has a negative relationship with all leverage ratios although it is significant in case of STDR and TDR at $1 \%$ level. The result is consistent with the prediction of Pecking-order theory. It implies that the companies having high free cash flows finance their projects with internal financing rather than external debt financing.

\subsubsection{Agency Costs}

It is evident that Agency Costs have a significant negative impact on the STDR and TDR at $1 \%$ level. This result conforms to the prediction of Agency theory because the companies having more agency conflicts among the stakeholders will tend to use less debt in their capital structure. This negative result is consistent with Chowdhury (2004).

\subsubsection{Dividend Payment}

We have found dividend payment as a significant determinant of leverage ratio as it has a negative relationship with STDR and TDR at 10\% significance level. This negative relationship is consistent with the prediction of Signaling theory. When a company gives at least $10 \%$ cash dividend, it sends a signal to the public investors that the company has a potential of favorable future earnings and hence, the investors tend to discount the company's earnings at a lower rate. Therefore, the company can raise funds from the equity markets at lower costs. The negative result is consistent with Hossain and Ali (2012).

\subsubsection{Industry Classification}

To determine the impacts of industry classification on capital structure choice, I have assumed the engineering industry as the base industry among the 8 industries used in this study. The results indicate that leverage ratios of the selected industries are significantly different from that of engineering industry except the food and allied industry. The positive sign of the coefficients indicates that the leverage ratio of the respective industry is greater than that of the engineering industry to the extent of the respective coefficient and vice-versa. Hence, industry classification is also a significant determinant of capital structure of the manufacturing companies in Bangladesh. This result also supports the findings of Hossain and Ali (2012).

\subsection{Results of Random Effects Tobit Regression Model}

Since some companies have no long term debt in their capital structure (that means, some of values of the dependent variable LTDR in Model- II are 0), I have also applied the Random-effects Tobit Regression Model in order to verify the results obtained from the PCSE regression model. The results of this model are shown in Table 13. 
Table 13. Random effects tobit regression results of model- II (LTDR)

\begin{tabular}{|c|c|c|c|c|c|c|}
\hline \multicolumn{7}{|c|}{ Random-effects tobit regression Number of obs. $=740$} \\
\hline \multicolumn{7}{|c|}{ Group variable: company Number of groups $=74$} \\
\hline \multicolumn{7}{|c|}{ Random effects $\mathrm{u}_{-} \mathrm{i} \sim$ Gaussian Obs. per group: $\min .=10$} \\
\hline \multicolumn{7}{|l|}{ Avg. $=10$} \\
\hline \multicolumn{7}{|l|}{ Max. $=10$} \\
\hline \multicolumn{7}{|c|}{ Wald chi2 $(15)=126.12$} \\
\hline \multicolumn{7}{|c|}{ Log likelihood $=473.35269$} \\
\hline \multicolumn{7}{|c|}{ Prob. $>$ chi $2=0.0000$} \\
\hline LTDR & Coefficient & Std. Error & $\mathrm{z}$ & $P>|z|$ & \multicolumn{2}{|c|}{$95 \%$ Confidence Interval } \\
\hline MO & 0.1522 & 0.0428 & $3.55^{* * *}$ & 0.000 & 0.0682 & 0.2362 \\
\hline GR & -0.0301 & 0.0109 & $-2.76 * * *$ & 0.006 & -0.0514 & -0.0088 \\
\hline PR & -0.1099 & 0.0752 & -1.46 & 0.144 & -0.2573 & 0.0376 \\
\hline TANG & 0.2712 & 0.0350 & $7.74 * * *$ & 0.000 & 0.2025 & 0.3399 \\
\hline DSC & -0.0000005 & 0.000002 & -0.21 & 0.831 & -0.000005 & 0.0000004 \\
\hline LQR & 0.0026 & 0.0012 & $2.17 * *$ & 0.030 & 0.0002 & 0.0049 \\
\hline NDTS & 0.0113 & 0.0086 & 1.31 & 0.189 & -0.0056 & 0.0282 \\
\hline FC & -0.7674 & 0.1211 & $-6.34 * * *$ & 0.000 & -1.0048 & -0.5301 \\
\hline FCFF & 0.00000004 & 0.0000001 & 0.44 & 0.656 & -0.0000002 & 0.0000003 \\
\hline $\mathrm{ACD}$ & -0.0196 & 0.0611 & -0.32 & 0.748 & -0.1393 & 0.1001 \\
\hline DIV & 0.0067 & 0.0103 & 0.64 & 0.519 & -0.0136 & 0.0270 \\
\hline d_cem & -0.1093 & 0.0798 & -1.37 & 0.171 & -0.2657 & 0.0472 \\
\hline d_food & -0.0253 & 0.0714 & -0.35 & 0.723 & -0.1652 & 0.1145 \\
\hline d_tex & -0.0478 & 0.0570 & -0.84 & 0.402 & -0.1594 & 0.0639 \\
\hline d_pharma & -0.0852 & 0.0635 & -1.34 & 0.180 & -0.2097 & 0.0393 \\
\hline _cons & 0.0478 & 0.0496 & 0.96 & 0.335 & -0.0494 & 0.1450 \\
\hline
\end{tabular}

Note. Here, $*$,** and *** represent $10 \%, 5 \%$ and $1 \%$ significance level respectively.

Here, it is evident that the results of Random-effects Tobit Regression Model are as the same as those of PCSE results of Model- II in terms of the coefficient signs and their significance level except the industry dummy variable. The overall model is also significant at $1 \%$ significance level as Prob. $>$ chi 2 is 0.0000 . Hence, it can easily be concluded that the PCSE results of Model- II are satisfactory and reliable as they conform to those of Random-effects Tobit Regression Model.

\section{Testing of Capital Structure Theories}

Table 14. Summary of the testing of capital structure theories

\begin{tabular}{|c|c|c|c|c|c|c|c|c|c|}
\hline \multirow[b]{2}{*}{$\begin{array}{l}\text { Independent } \\
\text { Variables }\end{array}$} & \multicolumn{5}{|c|}{ Expected Signs } & \multicolumn{3}{|c|}{ Observed Signs* } & \multirow[t]{2}{*}{$\begin{array}{l}\text { Consistent Capital } \\
\text { Structure theory }\end{array}$} \\
\hline & $\begin{array}{l}\text { Agency } \\
\text { theory }\end{array}$ & $\begin{array}{l}\text { Static } \\
\text { Trade-off } \\
\text { theory }\end{array}$ & $\begin{array}{l}\text { Pecking } \\
\text {-order } \\
\text { theory }\end{array}$ & $\begin{array}{l}\text { Signaling } \\
\text { theory }\end{array}$ & $\begin{array}{l}\text { Free Cash } \\
\text { Flow theory }\end{array}$ & Model - I & Model -II & Model -III & \\
\hline MO & - & - & + & & & & + & + & Pecking-order theory \\
\hline GR & - & - & + & + & & & - & - & Static Trade-off theory \\
\hline PR & & + & - & + & & - & & & Pecking-order theory \\
\hline TANG & & + & - & & & - & + & - & $\begin{array}{l}\text { Pecking-order theory \& } \\
\text { Static Trade-off theory }\end{array}$ \\
\hline DSC & & + & - & & & & & - & Pecking-order theory \\
\hline LQR & & + & - & & & - & + & - & $\begin{array}{l}\text { Pecking-order theory \& } \\
\text { Static Trade-off theory }\end{array}$ \\
\hline NDTS & & - & & & & - & & - & Static Trade-off theory \\
\hline $\mathrm{FC}$ & & - & & & & - & - & - & Static Trade-off theory \\
\hline FCFF & & & - & & + & - & & - & Pecking-order theory \\
\hline $\mathrm{AC}$ & - & & & & & - & & - & Agency theory \\
\hline DIV & & & + & - & & - & & - & Signaling theory \\
\hline
\end{tabular}

Note. Here, $*$ represents that only significant observed signs are reported here. 
One of the objectives of this study was to test the capital structure theories applicable for the manufacturing companies in Bangladesh. Based on the PCSE regression results, the summary of the testing of capital structure theories is given in Table 14 .

It is evident that four independent variables i.e. managerial ownership, profitability, debt service coverage and free cash flow to firm follow the Pecking-order theory whereas three variables i.e. growth rate, non-debt tax shield and financial costs follow the Static Trade-off theory. On the contrary, two variables i.e. tangibility and liquidity follow both the Pecking-order theory and Static Trade-off theory. Agency costs and dividend payment follow the Agency theory and Signaling theory respectively. Hence, it can be suggested that the Pecking-order theory and the Static Trade-off theory are the two most relevant and dominant capital structure theories in Bangladesh.

\section{Conclusion and Policy Recommendations}

This study aims at investigating the significant determinants of capital structure of the listed manufacturing companies in Bangladesh and also testing the relevant capital structure theories. We have used a panel data set including 74 manufacturing companies listed under 8 industries in Dhaka Stock Exchange for 10 year time period (2002-2011). The selected industries are: Cement, Ceramic, Engineering, Food \& Allied, Jute, Pharmaceuticals \& Chemicals, Tannery and Textile industry. We have used three regression models based on three dependent variables (i.e. Short term debt ratio, Long term debt ratio and Total debt ratio) and each model includes twelve independent variables. We have done two unit root tests (i.e. Levin-Lin-Chu Test and Fisher-type ADF Test) in order to check the stationary properties of the series and found all series stationary at level. The data set had no multicollinearity problem; rather it had the problem of heteroscedasticity and positive serial autocorrelation. That's why we have applied the Panel Corrected Standard Error (PCSE) regression model as it automatically corrects the problem of heteroscedasticity and autocorrelation and provides the best estimates of the variables. As some of the companies had no long term debt (that means, some of the values of dependent variable in Model- II was 0), Random Effects Tobit Regression Model was also run to verify the results and this model supported the results obtained from the PCSE regression model.

It is evident from the results of PCSE regression models that all of the selected variables are the significant determinants of capital structure of the listed manufacturing companies in Bangladesh. Managerial ownership was found to have positive influence on the leverage ratios. On the contrary, Growth rate, Profitability, Debt service coverage ratio, Non-debt tax shield, Financial costs, Free cash flow to firm, Agency costs and Dividend payment have negative relationship with the leverage ratios. Tangibility and Liquidity ratio have positive relationship with Long term debt only but negative relationship with Short term debt and Total debt. It was also found that the capital structure of various industries of Bangladesh differs significantly from each other. The results also suggest that the Pecking-order theory and the Static Trade-off theory are the most dominant capital structure theories in Bangladesh.

This study has important policy implications for the financial managers as well as the researchers. The financial managers should consider these determinants as yardsticks before taking the leverage decisions in order to choose the most favorable capital structure for the company so that it maximizes the shareholders' value. On the contrary, the researchers can utilize the findings and methodology of this study for their further research and also incorporate some other important factors (i.e. managerial behavior, credit rating, potential costs of financial distress, financial flexibility, project's risk etc.) along with larger panel data set with a view to getting a better depiction of the capital structure of the Bangladeshi companies.

\section{Acknowledgements}

We would like to give our heart-felt thanks to Dr. A. A. Mahboob Uddin Chowdhury, Professor of Finance, University of Dhaka, for his great assistance and fruitful suggestions in conducting this study.

\section{References}

Akhtar, S. (2005). The Determinants of Capital Structure for Australian Multinational and Domestic Corporations. Australian Journal of Management, 30(2), 321-341. http://dx.doi.org/10.1177/031289620503000208

Bancel, F., \& Mittoo, U. R. (2004). Cross-Country Determinants of Capital Structure Choice: A Survey of European Firms. Financial Management, 33, 4.

Baral, K. J. (2004). Determinants of Capital Structure: A Case Study of Listed Companies of Nepal. Journal of Nepalese Business Studies, 1(1), 1-13. http://dx.doi.org/10.3126/jnbs.v1i1.34 
Bevan, A., \& Danbolt, J. (2000). Dynamics in the Determinants of Capital Structure in the UK. University of Glasgow, Working Paper, 1-10.

Choi, I. (2001). Unit Root Tests for Panel Data. Journal of International Money and Finance, 20, $249-272$. http://dx.doi.org/10.1016/S0261-5606(00)00048-6

Chowdhury, M. U. (2004). Capital Structure Determinants: Evidence from Japan and Bangladesh. Journal of Business Studies, $X X V(1), 23-45$.

Durbin, J., \& Watson, G. S. (1950). Testing for Serial Correlation in Least Squares Regression. I. Biometrika, 37, 409-428.

Frank, M. Z., \& Goyal, V. K. (2007). Capital Structure Decision: Which Factors Are Reliably Important? Social Science and Research Network, Working Paper Series.

Graham, J. R., \& Harvey, C. R. (2001). The Theory and Practice of Corporate Finance: Evidence from the Field. Journal of Financial Economics, 60(2-3), 187-243. http://dx.doi.org/10.1016/S0304-405X(01)00044-7

Gujarati, D. N. (2007). Basic Econometrics. India: Tata McGraw-Hill Edition.

Hassan, S. U. (2011). Determinants of Capital Structure in the Nigerian Listed Insurance Firms. International Conference on Management Proceeding.

Honore, B. E. (1992). Trimmed LAD and Least Squares Estimation of Truncated and Censored Regression Models with Fixed Effects. Econometrica, 60, 533-565. http://dx.doi.org/10.2307/2951583

Hossain, M. F., \& Ali, M. A. (2012). Impact of Firm Specific Factors on Capital Structure Decision: An Empirical Study of Bangladeshi Companies. International Journal of Business Research and Management, 3(4), 163-182.

Huang, S. G. H., \& Song, F. M. (2002). The Determinants of Capital Structure: Evidence from China. Hong Kong Institute of Economics and Business Strategy, Working Paper.

Jensen, M. (1986). Agency Costs of Free Cash Flow, Corporate Finance and Takeovers. American Economic Review, 76(2), 323-329.

Jensen, M., \& Meckling, W. (1976). Theory of the Firm: Managerial Behavior, Agency cost and Ownership Structure. Journal of Financial Economics, 3, 305-360. http://dx.doi.org/10.1016/0304-405X(76)90026-X

Kmenta, J. (1997). Elements of Econometrics (2nd ed.). Ann Arbor: University of Michigan Press.

Levin, A., Lin, C. F., \& Chu, C. S. J. (2002). Unit Root Tests in Panel Data: Asymptotic and Finite-Sample Properties. Journal of Econometrics, 108, 1-24. http://dx.doi.org/10.1016/S0304-4076(01)00098-7

Lewis-Beck, M. S. (1993). Applied Regression: An Introduction in Regression Analysis. Singapore: Sara Miller McCune, Sage Publications Inc.

Lima, M. (2009). An Insight into the Capital Structure Determinants of the Pharmaceutical Companies in Bangladesh. GBMF Conference.

Mazhar, A., \& Nasr, M. (2010). Determinants of Capital Structure Decisions Case of Pakistani Government Owned and Private Firms. International Review of Business Research Papers, 6, 40-46.

Mishra, C. S. (2011). Determinants of Capital Structure- A Study of Manufacturing Sector PSUs in India. International Conference of Financial Management and Economics, 11.

Modigliani, F., \& Miller, M. H. (1958). The Cost of Capital, Corporate Finance and the Theory of Investment. American Economic Review, 48, 261-297.

Myers, S. C., \& Majluf, N. (1984). Corporate Financing and Investment Decisions when Firms have Information Investors don't have. Journal of Financial Economics, 13, 187-221. http://dx.doi.org/10.1016/0304-405X(84)90023-0

Pandey, I. M. (2001). Capital Structure and the Firm Characteristics: Evidence from an Emerging Market. IIMA Working Paper, No. 2001-10-04.

Pathak, J. (2005). What Determines Capital Structure of Listed Firms in India? Some Empirical Evidences from the Indian Capital Market. Social Science and Review Network.

Pearson, K. (1896). Mathematical Contributions to the Theory of Evolution-III, Regression, Heredity and Panmixia. Philosophical Transactions of the Royal Society of London, Series A-187, 253-318. http://dx.doi.org/10.1098/rsta.1896.0007 
Rafiq, M., Iqbal, A., \& Atiq, M. (2008). The Determinants of Capital Structure of the Chemical Industry in Pakistan. Lahore Journal of Economics, 13(1), 139-158.

Rajan, R. G., \& Zingales, L. (1995). What Do We Know about Capital Structure? Some Evidence from International Data. The Journal of Finance, 10(5), 1421-1460. http://dx.doi.org/10.1111/j.1540-6261.1995.tb05184.x

Rao, S. N., \& Jijo, L. P. J. (2001). Determinants of Capital Structure in India: A Comparative Study of Pre-and-Post Liberalization Regime. The Journal of Management and Accounting Research.

Sayeed, A. M. (2011). The Determinants of Capital Structure for Selected Bangladeshi Listed Companies. International Review of Business Research Papers, 7(2), 21-36.

Scott, J. (1977). Bankruptcy, Secured Debt and Optimal Capital Structure. The Journal of Finance, 32, 1-19. http://dx.doi.org/10.1111/j.1540-6261.1977.tb03237.x

Shah, A., \& Hijazi, T. (2004). The Determinants of Capital Structure of Stock Exchange Listed Non-Financial Firms in Pakistan. The Pakistan Development Review, 43(4), 605-618.

Siddiqui, S. S. (2012). Capital Structure Determinants of Non-Bank Financial Institutions (NBFIs) in Bangladesh. World Review of Business Research, 2(1), 60-78.

Titman, S., \& Wessels, R. (1988). The Determinants of Capital Structure Choice. The Journal of Finance, 43 , 1-18. http://dx.doi.org/10.1111/j.1540-6261.1988.tb02585.x

Vasiliou, D., \& Daskalakis, N. (2006). The Practice of Capital Structure in a Small Market and a Cross-National Comparison. Social Science and Review Network, Working Paper.

White, H. (1980). A Heteroscedasticity Consistent Covariance Matrix Estimator and a Direct Test of Heteroscedasticity. Econometrica, 48, 817-818. http://dx.doi.org/10.2307/1912934

\section{Notes}

Note 1 . The value is standardized by dividing FCFF by 10000 following Akhtar (2005) and Sayeed (2011).

Note 2. Proxy of Agency Costs is determined following Titman and Wessels (1988) and Akhtar (2005).

Note 3. Strongly balanced panel dataset means each panel must have the same number of observations and cover the same time span.

\section{Copyrights}

Copyright for this article is retained by the author(s), with first publication rights granted to the journal.

This is an open-access article distributed under the terms and conditions of the Creative Commons Attribution license (http://creativecommons.org/licenses/by/3.0/). 